\title{
Question (a)
}

I. Claims pursuant to $\S 906(2)$ sentence 2 of the Civil Code ${ }^{172}$ for property damage

1. The first requirement for a compensatory claim pursuant to $\$ 906(2)$ sentence 2 Bürgerliches Gesetzbuch (BGB, or Civil Code) ${ }^{173}$ under the law of nuisance (Nachbarrecht) is that $B$ has standing as the owner or authorised occupant of an adjoining property. ${ }^{174}$ No factual explication is given on this point.

The second element is the existence of a significant infringement to $B$ 's property rights, in the form of an impact on the land above reasonably acceptable limits. An infringement is insignificant pursuant to $\S 906(1)$ sentence 2 BGB if it does not exceed the substantive limits or norms (legal standards) set by public law. Thus, $\S 906(1)$ sentence 3 BGB equates the substantive law on this point with the administrative regulations under $\S 48 \mathrm{BImSchG}$ (Federal Emission Control Act). ${ }^{175}$ In fact, under $\S 906(2)$ sentence 1 BGB, B may be required to tolerate the emissions from $A$ 's property. To deny $B$ any remedy under this provision, A's use of the installation would have to be customary for the locality (ortsüblich), and any measures which might prevent the significant infringement of B's rights would have to be deemed unreasonable for $A$ ( $\$ 906(2)$ sentence 1 BGB). Nevertheless, courts may find a significant infringement where the limits or legal values are not exceeded, ${ }^{176}$ using instead the perception of the average person as a standard. In determining the significance of an infringement based on such a standard, the type and designated purpose of the affected land are of decisive importance. ${ }^{177}$

A use is customary for a locality containing an installation if the majority of similar properties are used with similar adverse effects on other properties. ${ }^{178}$ In judging the reasonableness of possible preventive measures, courts must determine whether the average installation of the type causing the nuisance can be expected to bear the financial burden of the necessary measures. ${ }^{179}$ In other words, if the cost of preventative measures is at such a level that the comparable, average company could no longer realise an appropriate counterbalancing profit, a measure is no longer 'financially reasonable'. ${ }^{180}$ However, the

18.8.1896, RGBl. p. 195. ${ }^{173}$ German Civil Code, hereinafter BGB.

Cf., for example, BGH 15.4.1959, BGHZ 30, 273, 276; BGH 14.10.1994, NJW 1995, 132; Staudinger/Roth, BGB, 13th edn, 2002, § 906 n. 231.

4.5.1990, BGBl. I p. 880. ${ }^{176}$ Palandt/Bassenge, BGB, 63rd edn, 2004, §906 n. 23.

BGH 6.2.1986, BGHZ 97, 97, 104. 178 BGH 20.11.1992, BGHZ 120, 239, 260.

taudinger/Roth, BGB § 906 n. 207.

Soergel/Baur, BGB, 13th edn, 2002, § 906 n. 98. 
Bundesgerichtshof ${ }^{181}$ applies $\S 906(2)$ sentence 2 BGB correspondingly if an illegal emission under $\S 906$ BGB cannot, for specific reasons, be prevented by the owner or occupier of the property. ${ }^{182}$ Since the necessary specific facts in Question 1(a) are not given, it cannot be answered definitively whether $B$ has a claim against $A$ pursuant to $\S 906(2)$ sentence 2 BGB.

2. Provided that $B$ is under no duty of tolerance under $\S 906 \mathrm{BGB}$, he can demand the removal of the infringement pursuant to $\S 1004(1)$ sentence $1 \mathrm{BGB}$, unless he is otherwise required to tolerate the nuisance pursuant to $\S 14$ sentence 1 item 1 BImSchG. The existence of a duty of toleration depends on whether the plant's licence may be challenged. Again, this question cannot be answered for the situation in Question 1(a) on the basis of the facts given.

3. If there is, in fact, a duty of toleration under $\S 14$ sentence 1 item 1 BImSchG, B can instead claim compensation from $A$ pursuant to $\S 14$ sentence $2 \mathrm{BImSchG}$, if the preventative options for $A$ are, again, technically impracticable or economically unreasonable.

4. A claim under § 1 UmweltHG (Environmental Liability Act) ${ }^{183}$ is only actionable against one of the plants designated in Appendix 1 if its environmental impact causes B's damage. Environmental impacts pursuant to § 3(1) UmweltHG include substances, vibrations, noise, pressure, rays, gases, fumes, heat emissions or other phenomena which are disseminated in the soil, air or water. Installations pursuant to $\S 3(2)$ UmweltHG are stationary facilities, such as operational facilities and warehouses. However, the emitting plant (in the interests of legal certainty and clarity) ultimately must belong to the categories in Appendix 1 UmweltHG, a category designated by the legislature as particularly hazardous. Section 1 UmweltHG is a strict liability provision.

Liability arising from force majeure is excluded pursuant to $\S 4$ UmweltHG. Section 5 UmweltHG also excludes liability for property damage if (i) the installation is operated within the requirements of $\S 6(2)$ sentence 2 UmweltHG, and (ii) the affected property is only minimally impaired, or impaired only to a reasonably acceptable extent under local conditions. Section 15 UmweltHG sets a maximum liability limit at $€ 85$ million for property damage caused by a single environmental impact.

5. Under § 22(1) sentence 1 WHG (Water Supply Code), ${ }^{184}$ anyone who introduces or discharges any substance into a body of water, or otherwise detrimentally affects the water, such that the physical, chemical or biological properties of the water are changed, is subject to liability. 'Introduction' of a substance means contamination by solid 
substances, while 'discharge' of a substance refers to contamination by liquid or gaseous substances. 'Impact' on water includes drawing off, damming or heating. ${ }^{185}$ Introduction, discharge or another impact are intentional acts. ${ }^{186}$ Thus liability under $\$ 22(1)$ sentence 1 WHG does not apply to harmful substances that enter a body of water due to a disturbance or an accident. ${ }^{187}$ The given facts in Question 1(a) are insufficient to determine whether $A$ has, in fact, introduced or discharged substances or impacted water, pursuant to $\S 22(1)$ sentence 1 WHG.

6. Under $\S 22(2)$ sentence $1 \mathrm{WHG}$, an installation causing substances to enter a body of water may be liable for damages. An installation here refers to any plant which is intended to produce, process, store, keep, transport or conduct water-contaminating substances. ${ }^{188}$ The concept of an installation is broad and not limited to immovable installations in a locality. ${ }^{189}$

7. There may be a claim for property damage under $\S 823(1)$ BGB, which is applicable pursuant to $\S 18(1)$ UmweltHG. However, a claim under $\S 823(1)$ BGB requires fault on A's part, which is not the case in Question 1(a). However, with respect to product liability, the $B \mathrm{BH}^{190}$ reverses the burden of proof for fault, if the cause of damage constitutes a significant infringement under $\S 906$ BGB. The BGH justifies this reversal of the burden of proof on the grounds that the injured party is not in a position to take a view of the operating conditions leading to the emissions, and the operator is in a better position to put forward the facts relevant to the elements of the tort. Whether there is a significant infringement in the Question 1(a) scenario is unclear because of the incomplete facts in this regard (see point I.1 above).

8. A claim under $\S 823(2)$ BGB in connection with a penal protective law does not apply because of a lack of inculpatory evidence.

\section{Claims for personal injury and damage to health}

1. To the extent that $B$ is owner or authorised occupant of an adjoining property, a claim under § 906(2) sentence 2 BGB should be considered. However, since, under this section, impacts are only deemed significant

Schimikowski, Umwelthaftungsrecht und Umwelthaftpflichtversicherung (6th edn, 2002),

n. 100.

Czychowski, Wasserhaushaltsgesetz, (7th edn, 1998), § 22 n. 7.

Czychowski, Wasserhaushaltsgesetz $\S 22 \mathrm{n}$. 8. Here the omission of preventative measures can result in damage liability. This, however, requires a corresponding duty and that the setting of a positive act would have prevented the damage with a degree of likelihood close to certainty. Furthermore, the inaction must be purposeful with regard to the water.

189 Cf. ibid., n. 108; Czychowski, Wasserhaushaltsgesetz § 22 n. 43; BGH 22.11.1971, BGHZ 57, 257, 259. 
based upon the average person's perception, ${ }^{191}$ it may be assumed that death, personal injury or damage to health are perceived as 'significant' to the average person, and thus the nuisance is no longer an acceptable infringement. Furthermore, $B$ must not be under a duty pursuant to $\S 906(2)$ sentence 1 BGB to tolerate the emissions emanating from $A$ 's property. If $A$ is using the property in a manner customary for the locality, and it would be unreasonable to expect $A$ to take measures to prevent the significant infringement, then there is a duty of toleration on B. However, the facts in Question 1(a) give no indication of a duty of toleration nor whether $B$ was actually prevented from averting the emission infringement pursuant to § 1004(1) BGB (§ 906(2) sentence 2 BGB). Nevertheless, $B$ can demand cessation of the infringement under $\S 1004$ (1) sentence 1 BGB if he is not under a duty of toleration pursuant to $\S 906$ BGB.

2. A claim under $\S 1$ UmweltHG is also possible. This provides for damages for injury to health due to the environmental impact of an installation specified in Appendix 1. If $A$ is running such an installation, then he is strictly liable. However, liability is excluded pursuant to § 4 UmweltHG if the damage has been caused by force majeure. Section 5 UmweltHG limits liability only as to marginal and reasonable material damage, and is therefore not applicable here. The maximum liability for death as well as personal injury or damage to health is $€ 85$ million ( $§ 15$ sentence 1 UmweltHG).

3. $B$ has a claim against $A$ for death or personal injury or damage to health under $\S 22(1)$ sentence 1 WHG or § $22(2)$ sentence 1 WHG. Injuries to health are subject to the same requirements as property damage under these sections (see the discussion in points I.5. and 1.6 above).

4. Life, the person and health are also protected under $\S 823(1)$ BGB. In view of the above-mentioned reversal of burden of proof relating to fault, no provisions are applicable here as the fault question arises independently of the type of legal interest in $\S 823(1)$ BGB that has been violated. In addition, $B$ has a claim against $A$ in case of personal injury or damage to health derived from § 253(2) BGB, or general compensation of non-property damage.

\section{Claims arising from death}

In the case of B's death, only claims by third parties may be considered.

1. The heirs can pursue claims, which descend to them by universal succession under § 1922(1) BGB. 
2. The tortious act entitles B's heirs to claim funeral costs under $\S 844(1)$ BGB; compensation for dependants under $\S 844(2)$ BGB; and indemnification pursuant to $\S 845$ sentence 1 BGB for the person to whom $B$ owed a legal duty to provide services. The claims arising from $\S \S 844$ and 845 BGB correspond to strict liability under $\S 12$ UmweltHG.

\section{Question (b)}

I. Minor property damage

1. A claim under $\S 906(2)$ sentence 2 BGB requires a significant infringement beyond what is reasonably acceptable, as discussed above. Here, the legal norms of administrative regulations under $\S 48$ BImSchG are relevant. Nevertheless, again, liability may also attach where regulatory limits are not exceeded (see the discussion in Question 1(a), point I.1 above).

2. If $B$ is not subject to a duty of toleration under $\S 906 \mathrm{BGB}$, then he may demand the removal of the infringement by $A$ pursuant to $\S 1004(1)$ sentence $1 \mathrm{BGB}$.

3. A claim under $\S 1$ UmweltHG may fail, however, due to the liability exclusion under $\S 5$ UmweltHG. The precondition for the exclusion is that the installation be operated in accordance with its intended purpose. ${ }^{192}$

\section{Minor health impairment}

1. With minor health impairment, the relevant question is whether there is a significant infringement beyond what may reasonably be acceptable pursuant to $\S 906(2)$ sentence 2 BGB. Impacts are generally insignificant if an average person can hardly perceive them, ${ }^{193}$ so it would appear that an impairment such as chronic bronchitis would be likely to be perceivable, and, therefore, significant. Nevertheless, where there are threats to health by emissions, the local customary standard will normally be exceeded at that point, so there would be no duty of toleration. ${ }^{194}$ Despite the absence of a duty, however, a claim analogous to one under $\S 906(2)$ sentence 2 BGB is possible if B was prevented by circumstance from averting the emissions, including where he has no knowledge of the emissions. Otherwise, there is no difference in the jurisprudence regarding this scenario and that discussed in Question 1(a), point II.1 above.

192 Finally, note that no new claims for either minor property damage or minor health impairment arise under §§ 22(1) s. 1, (2) s. 1 WHG, or § 823(1) BGB (see Question 1(a) II.3, 4). 
2. Where, as here, $B$ is most likely under no duty of toleration pursuant to $\S 906$ BGB, B can demand cessation of the infringement by $A$ under $\S 1004(1)$ sentence 1 BGB.

3. Liability is also incurred for minor health impairment under § 1 UmweltHG.

4. The claim under $\S 823(1)$ BGB requires damage to health, specifically. In order to prove damage to health, according to the dominant opinion in civil law literature, there needs to be an objectively ascertainable disturbance, which in magnitude, strength and duration exceeds the limits of negligibility, is clinically diagnosable, or, at least, leads to a short-term pathological condition. ${ }^{195}$ In addition, a physiological alteration to health is required, ${ }^{196}$ and it may further be required that the injury necessitates medical treatment. ${ }^{197}$ An impairment of well-being without any symptoms of sickness, on the other hand, will not be deemed to amount to damage to health. ${ }^{198}$ 'Illness' is the conceptually opposite condition to 'health' ${ }^{199}$ Civil law and public law jurisprudence defines the legal interest of health more broadly than the legal literature. The Supreme Court of the German Reich and Federal Supreme Court understand damage to health as a disturbance of the inner bodily life processes or of an emotional and mental nature. ${ }^{200}$ The creation or accentuation of any adverse physical condition is sufficient for the affirmation of a bodily (physical) damage to health. It is immaterial whether pain is present or whether a radical alteration in the state of health has subsequently occurred. ${ }^{201}$ Mental injury, such as a nervous disease, ${ }^{202}$ a nervous breakdown ${ }^{203}$ or an accident neurosis ${ }^{204}$ are also injuries to health. Here, an organic cause is not required. ${ }^{205}$ For a claim pursuant to $\S 823(1)$ BGB, however,

Deutsch, 'Die Gesundheit als Rechtsgut im Haftungs- und Staatshaftungsrecht', KF 1983, 93, 94; Staudinger/Schäfer, BGB, 12th edn, 1986, § 823 n. 26; RGRK/Steffen, BGB, 12th edn, 1986, § 823 n. 10; for § 1 UmweltHG, see Landsberg/Lülling, Umwelthaftungsrecht, $1991, \S 1$ n. 28. RGRK/Steffen, BGB § 823 n. 10.

MünchKomm/Mertens, BGB, 3rd edn, 1996, § 823 n. 55 et seq. GRK/Steffen, BGB § 823 n. 10; Staudinger/Schäfer, BGB § 823 n. 24.

Landsberg and Lülling, Umwelthaftungsrecht § $1 \mathrm{n} .28$. BGH 20.12.1952, BGHZ 8, 243, 248 (lues infection through blood products). See also Möllers, Rechtsgüterschutz im Umwelt- und Haftungsrecht (1996), p. 35. cases in which no illness has due to lack of immunity has occurred); BGH 20.12.1952, BGHZ 8, 243, 245 (infection of mother and unborn child through blood products); also Palandt/Sprau, BGB § 823 n. 4.

202 See RG 5.10.1914, RGZ 85, 335 for the adverse psychological effects of marriage failure. OLG Oldenburg 6.7.1990, NJW 1990, 3215 (nervous breakdown and threats of suicide as a result of low-level flights).

${ }^{204}$ BGH 12.11.1985, NJW 1986, 777 (neurosis of an accident victim).

205 BGH 9.4.1991, VersR 1991, 704 (psychological effects of an accident). 